Relations industrielles

Industrial Relations

\title{
An Outline of our Fourth Convention
}

\section{Gérard Tremblay}

Volume 4, numéro 6, février 1949

URI : https://id.erudit.org/iderudit/1023495ar

DOI : https://doi.org/10.7202/1023495ar

Aller au sommaire du numéro

\section{Éditeur(s)}

Département des relations industrielles de l’Université Laval

\section{ISSN}

0034-379X (imprimé)

1703-8138 (numérique)

Découvrir la revue

Citer cet article

Tremblay, G. (1949). An Outline of our Fourth Convention. Relations

industrielles / Industrial Relations, 4(6), 51-52. https://doi.org/10.7202/1023495ar

Tous droits réservés @ Département des relations industrielles de l’Université Laval, 1949
Ce document est protégé par la loi sur le droit d'auteur. L’utilisation des services d'Érudit (y compris la reproduction) est assujettie à sa politique d'utilisation que vous pouvez consulter en ligne.

https://apropos.erudit.org/fr/usagers/politique-dutilisation/ 


\section{Bulletin des relations industrielles}

\section{AN OUTLINE OF OUR FOURTH CONVENTION \\ Gérard Tremblay}

The Bulletin is published monthly, September to June inclusively (ten issues a year). Annual subscription: Canada: $\$ 1.50$; Foreign: $\$ 2.00$. Single copies: twenty-five cents.

Publication indexed in the "Canadian Index".

All correspondance must be addressed to the Literary Editor Geraro Dion 2, University Street, Quebec.

Bulletin des relations industrielles

\begin{tabular}{ll}
\hline Volume 4, number 6 & February 1949 \\
\hline
\end{tabular}

Contents

An Outline of our Fourth Convention Gérard Tremblay..

The Family Budget and Wage

Adiustments

Jean-Marie Martin

The Young and the Building Trades Marcel Clément

Union Security in Great Britain Gérard Dion.

The Eduational Service of the C.T.C.C. Fernand Jolicoevr

A reader's comments: The Future of the Collective Agreement Act

\section{Contributors}

Bancroft, (Mrs.) M.T. Translator of the Bulletin.

Clément, Marcel, Licencié ès Lettres, diplòmé d'études supérieures en philosophie (Sorbonne), licencié en droit, diplômé d'études supérieures d'économie politique (Faculté de droit de Paris), Professor, Faculty of Social Sciences, Laval University.

Dion, Gérard, L.Th., L.Phil., M.Soc.Sc., Professor, Assistant-Director, Department of Industrial Relations, Faculty of Social Sciences, Laval University.

Jolicoeur, Fernand, B.A., M.Soc.Sc., Director, Eduational Service of the Canadian and Catholic Confederation of Labour.

Martin, Jean-Marie, B.A., L.S.A. (Montreal), M.S.A. (Cornell), Professor, Director, Department of Economics, Faculty of Social Sciences of Laval University.

Authorized as second class mail Post-office Department, Ottawa, Canada.
The last Convention of the Department of Industrial Relations chose as its theme Employer-Employee Co-operation on the plane of the collective labour agreement, on that of vocational training, on that of industrial security and hygiene and on that of joint enterprise committees. The subject certainly lacked neither diversity nor breadth. Problems so many and so urgent require the consideration of a Convention such as ours so, no doubt, we were forgiven that necessary dispersion. Is it not essential to stir up general ideas on the solution of the questions involved and come back to a particular one amongst them on the first occasion?

It was in this spirit that the administration of the Department thought it opportune to propose this year as principal subject for the Fourth Conference: - The Techniques of Labour Relations.

The subject, as one can see, is bound up to a great extent with employer-employee co-operation on the level of the collective agreement. Nevertheless, in taking it up again the Convention does not risk unnecessary repetition. Everybody agrees on the merits of labour agreements. Nonetheless, there is a technique which conditions the success of collective bargaining.

The speakers will explain, from the employers' and the workers' point of view in turn, certain aspects of the techniques of labour relations.

First of all, the technique of the organization of employers' and employees' groups! Syndicalism is acknowledged as morally necessary. What are the best methods of convincing those concerned? How bring about their education? Does employer syndicalism develop in a parallel direction with unionism thus facilitating contacts on the level of the enterprise, and on that of industry and commerce?

Secondly, it is admitted that the chief responsibility for collective bargaining lies with the interested parties. Agreed, but is the technique of these negotiations perfected amongst us? Serious negotiations, worthy of the name suppose preparation and method. How succeed? This will be a second aspect which our associates will study. 
Thirdly, if the persons concerned sign a collective agreement its enforcement must be supervised. Mixed commissions can have this responsibility; sometimes it falls upon the union official and the company representative. How regulate grievances? What should be the behaviour of the accountable delegates? In short, there is the highly technical problem of the administration of collective agreements to be explained by our chairmen.

The recourse to conciliation, to mediation and above all the appeal to arbitration foreseen by our legislation also raises difficulties for the two parties in litigation. Strict procedures must be followed in arbitration. The preparation of the suit demands competence and judgment. It is necessary to prepare the proceedings carefully, summon witnesses and experts, participate in the discussions. And the arbitrators themselves should be particularly well-versed in the considerations which will guide the decisions of the arbitration sentence. We will study the technical aspect of arbitration procedure.

Labour relations can no longer, we know, develop by chance or in a slip-shod manner. They require principles of honesty, on the part of the participants in order to be maintained in real and fair balance, and also techniques which measure up to the importance of the stake - that stake which is the maintainance of social peace through a wise division of wealth.

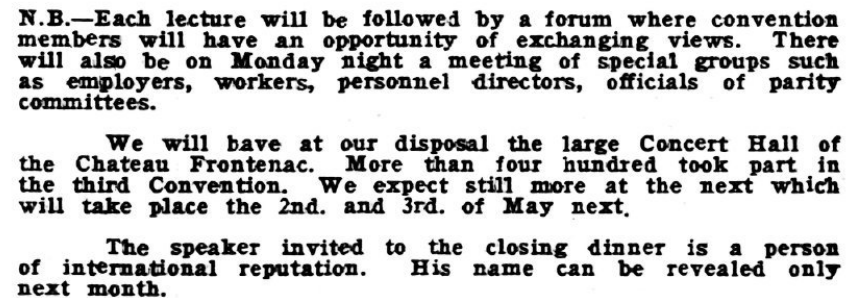
N.B.-Each lecture will be followed by a forum where convention will also be on Monday night a meeting of special groups such as employers, workers, personnel directors, officials of parity the Chateau Frontenac. More than four hundred took part in will take place the 2 nd. and 3rd. of May next. next month.

\section{THE FAMILY BUDGET AND WAGE ADJUSTMENTS,}

Jean-Marie Martin

In án article appearing in our January number we were lead to the conclusion that the Cost of Living Index has for its only function the measuring of variations occurring in the retail price of certain well-defined services and marchandise in the course of a given period. It should be pointed out as well at the beginning of this second article, that the Index is concerned solely with those essential products which frequently constitute only an existence minimum, and that the initial period (that which served as base for the setting up of the index) was still, in many parts of the country, a period of depression. Hence the living standard which this index reveals cannot, in consequence, correspond with a normal level of life.

It is evident then from the previous statements that the Cost of Living Index is certainly not the best argument to produce when wage adjustments

(1) This article is mainly composed of notes and constitutes rather a series of remarks than a bonafide article. are in question. In my opinion, the family budget can demonstrate more precisely the need of an augmentation or reduction in wages. It constitutes, assuredly, the most exact means of measuring the real needs of real families.

François Perroux, in a study of the science of man and the science of economics ${ }^{2}$ confirms the preceding when he studies the problem of minimum wage. "To calculate it», he says, «we must start with a typical budget of worker's consumption; but, if drawn from purely economic facts this signifies little. It appears more and more indispensable to correct it by biological data (number of calories and vitamins) and even by psychological data (social performance, etc.)».

Nevertheless, when we construct a family composition according to many factors, of which

(2) “Trois essais sur la science de l'homme” par le Dr R. Barthe, M. Caullery, François Perroux, Librairie de Médicis, Paris 1943. 